UDK: 821.511.141.03=163.41; 821.511.141.09-31 Костолањи Д.

\title{
- JEDAN LIRSKI ELEMENT U ROMANU ZLATNI ZMAJ DEŽEA KOSTOLANJIJA, SAGLEDAN IZ PREVODILAČKE PERSPEKTIVE
}

\author{
MARKO ČUDIĆ 1 \\ Univerzitet u Beogradu, \\ Filološki fakultet, Katedra za hungarologiju, \\ Beograd, Srbija
}

Autor ovog rada fokusirao se na poetičke aspekte i estetičke implikacije jednog konkretnog prevodilačkog problema u romanu Zlatni zmaj (1925) klasika mađarskog modernističkog pripovedanja, Dežea Kostolanjija (Kosztolányi Dezső, 1885-1936), koji se potvrdio i kao izuzetan pesnik. Za razliku od drugih prozaista njegovog vremena, kod kojih bi rima u prozi mogla biti znak nepažnje ili lošeg stila, Kostolanjijev narator, po mišljenju autora ovog rada, u jednom od najdramatičnijih trenutaka u romanu - a reč je o trenutku samoubistva glavnog junaka - svesno pribegava jednom neobičnom ponavljanju te koristi rimu u prozi ne bi li, možda i sa sebi svojstvenom (autopoetičkom) ironijom naglasio svu teškoću da se opiše nesaznatljivo, tj. nešto što izmiče kategorijalnom razmišljanju i mogućnosti opisivanja, u ovom slučaju (nasilna i iznenadna) smrt junaka, odnosno junakova izneverena očekivanja bazirana na njegovim, čitavog života marljivo i sa entuzijazmom sticanim, prirodnonaučnim saznanjima. Rad se fokusira na teškoće u izboru rešenja koja su prevodiocu u ovom konkretnom slučaju bila na raspolaganju, kao i na (moguće) posledice odabira upravo ovog, a ne nekog drugog rešenja sa stanovišta romana kao celine.

Ključne reči: tehnika „pomnog” čitanja, naglašeni momenat, rima u prozi, prevodilačke teškoće.

Deže Kostolanji (Kosztolányi Dezső, 1885-1936), klasik mađarske književnosti iz perioda tzv. "estetskog modernizma" ili „estetske moderne" (dvadesete godine XX veka), kad god bi mu savremenici prebacivali - a prebacivali su mu prilično često - zbog nedovoljno jasno profilisane političke pozicije u uvek turbulentnoj srednjoevropskoj državi kakva je Mađarska, najčešće se od tih kritika branio tako što je, nasuprot njihovim zahtevima da se jasno izjasni kao homo moralis i homo politicus, sebe doživljavao i predstavljao kao homo aesthethicusa i homo ludensa. Kostolanji je

1 Kontakt podaci (Email): marko.cudic@gmail.com 
napisao veliki broj ogleda i esejističkih tekstova u kojima nastoji da dokaže da direktni angažman zapravo uništava literaturu, svodeći je na neduhoviti, jednodimenzionalni, neslojeviti pamflet. Njegov prvi, alegorični roman, Krvavi pesnik Neron (Nero, a véres költő, 1922), čija je radnja, slično kao i u Sjenkjevičevom delu Quo vadis? izmeštena u antički Rim, smatra se čak i ne preterano skrivenim obračunom sa savremenikom Dežeom Saboom (Szabó Dezső, 1879-1945). I premda se taj roman i danas može čitati s podjednakim uživanjem, čak i ako kontekst mnogima već odavno nije niti može biti poznat, pre svega kao izvanredna parabola 0 agresivnom i netalentovanom diletantu koji ima moć (glavni junak, odnosno negativni junak dela, Neron), filologija, a naročito kritičko izdanje Kostolanjijevih dela čiji je jedan segment već ugledao svetlost dana, nesumnjivo pokazuju da ni elementi želje za ličnim obračunom u ovom romanu ne manjkaju. Priređivač kritičkog izdanja ovog Kostolanjijevobg dela, klasični filolog Laslo Takač (Takács László) smatra, ipak, da je i ovaj roman, kao, uostalom, i svi drugi Kostolanjijevi romani, „,plod mukotrpnog i dugotrajnog razmišljanja” (Takács 2012: 28), gde se autor svojski trudio da izbegne direktne političke i lične invektive, kao i slučajna preklapanja sa nekim savremenim delima iz svetske književnosti sa sličnom tematikom (recimo, upravo i sa pomenutim Sjenkjevičevim delom).

Kostolanji se javio, kao i toliki drugi autori njegove generacije pre svega kao istančani lirik rilkeovskog senzibiliteta, i premda je uporedo sa pesmama pisao i putopise, književne i pozorišne kritike, vrcave novinske članke, pripovetke i romane, mnogobrojni se Kostolanjijevi tumači svakako slažu u jednom: u proznim delima ovog autora, bez obzira na žanr, snažno je izražena lirska, razigrana crta, dakle, upravo ono što bi, u nekoj zamišljenoj i, čini se, nepotrebno radikalnoj klasifikaciji, trebalo da odlikuje pisca kao homo aesthethicusa i homo ludensa. Ta lirska crta je na naročito slojevit i kompleksan način prisutna u Kostolanjijeva četiri romana, u pomenutom Krvavom pesniku Neronu, Ševi (Pacsirta, 1924), Zlatnom zmaju (Aranysárkány, 1925) i u Ani Edeš (Édes Anna, 1926). Ako sa ne malom dozom uopštavanja zaključimo da u prvom romanu, onom o Neronu, dominira istorijsko-alegorična dimenzija, a da u poslednjem - čiji je glavna junakinja primerna služavka "Slatka Ana" koja se iznebuha pretvara u hladnokrvnog ubicu svojih gospodara - prevagu odnose socijalnopsihološki elementi, onda bi se kao pravi primeri snažnim lirizmom prožete proze mogli uzeti romani Ševa i Zlatni zmaj, kao dela u kojima se pripovedač „vraća” u autorov rodni grad i mesto odrastanja, Suboticu, sa preko potrebnim izmeštanjem i ironijskim otklonom, razume se.

U ovim romanima razigrani pripovedač sa mešavinom lirizma i ironije (koja katkad prelazi i u otvoreni sarkazam) prikazuje provincijsku varošicu Šarseg, vršeći, na gotovo floberovski način, izvanrednu vivisekciju palanačkog mentaliteta. No, pripovedačevo neprestano poigravanje vidi se već i u samom nazivu grada - Šarseg bi se, naime, mogao prevesti kao Blatnjavi kutak, Blatnjavo ćoše, Blatnjavi budžak ili naprosto kao Blatište. I imena likova, naročito u romanu Ševa, uglavnom imaju i neko konkretno značenje ili na nešto asociraju, slično kao, recimo, kod Dostojevskog. Tako se, primera radi, Ševin otac zove Akoš Vajkai (Vajkay Ákos), gde bi se njegovo prezime moglo dovesti u vezu sa glagolom vájkál (u smislu preturati, rovariti po nečemu), a ako se zna da je Ševin otac opsednut heraldikom i crtanjem porodičnih stabala, pripovedačeva ironična invektiva na njegov račun prilično je jasna. Sličan je slučaj i sa jednim relativno sporednim likom 
u romanu, mladim pesnikom i urednikom Miklošom Ijašem (Ijas Miklós), koji smatra da je odavno prerastao malograđansku sredinu Šarsega i koji o sebi kao pesniku misli sve najbolje (premda čitalac romana nikakvu spoljnu potvrdu o njegovom daru zapravo ne dobija). Njegovo prezime, naime, mađarskog čitaoca sasvim očigledno asocira na imenicu ij, odnosno lûk - i zaista, mađarski bi se čitalac lako mogao zapitati da li su otrovne strelice koje on iz svog lûka odapinje prema gradu usmerene samo prema toj omrznutoj varošici i njenim neuglednim, zavidljivim stanovnicima ili se, u krajnjoj liniji, vraćaju njemu kao nekakve čudne bumerang-strelice koje ispaljuje sam pripovedač. Mnogo bi se još ovakvih primera moglo nabrojati, pa se vojvođanski teoretičar i kritičar prevoda Đerđ Pap (Papp György), osvrćući se u jednom prigodnom tekstu, objavljenom 1985. godine povodom stogodišnjice rođenja velikog pisca, sa pravom pita „zbog čega li se prvi srpskohrvatski prevodilac Ševe nije usudio da nekako pokuša da prevede" (Papp 1985: 1357) ova "govoreća" imena. ${ }^{2}$ Logično, ono što za srpske čitaoce kod Gogolja ili Dostojevskog i bez prevođenja može predstavljti prezime sa određenim značenjem, (makar i pogrešnim, ako se nasedne na zamku tzv. Iažnih prijatelja u srodnim jezicima), kao što su npr. Akakij Akakijevič, Raskoljnikov, Razumihin, Smerdjakov ili Njetočka Njezvanova, to bi se u slučaju nesrodnog jezika kakav je mađarski moralo prevesti ili nekako prilagoditi (kao što je činio, recimo, Stanislav Vinaver pri prevođenju Rablea, pa je dobijeno, primera radi, hibridno ime Granguzje i mnogo toga još). Postavlja se, naravno, pitanje da li je to moguće i dopušteno u ovom slučaju, dakle, kada pred sobom imamo prozu koja, za razliku od Rablea, ipak održava barem privid jednog modernog realističkog postupka.

Taj je realistički postupak, međutim, kako je već naglašeno, prožet snažnim lirizmom. Liričnost Kostolanjijeve proze, naročito kada je reč o romanima ovog autora, kao i kod većine dobrih pisaca, uostalom, nije nametljivo kitnjasta i sladunjava, već je, naprotiv, diskretna, dozirana s merom, i funkcioniše ne na nivou pojedinačnih scena, već na nivou dela kao celine. Ta se fina liričnost ogleda u prvom redu u izvanrednom osećaju za meru i za ritam proze, oličenom, primera radi, u sintaktičkom tkanju dela u kojem se, u zavisnosti od stepena dramatizacije ili ironizacije radnje, poseže za ritmičkim smenjivanjem kraćih i dužih rečenica, dijaloških i deskriptivnih pasaža, neočekivanih autorskih opaski i slično. U još ređe stilističke postupke ovog tipa spada ponavljanje reči ili rečenica, kojima Kostolanjijev pripovedač pribegava veoma retko, a kada to ipak učini, onda je za verovati da to čini sa dobrim razlogom.

$\mathrm{U}$ ovom tekstu bih se osvrnuo upravo na primer jednog takvog postupka ponavljanja, i to u drugom Kostolanjijevom romanu zavičajnog sveta, u delu Zlatni zmaj. Kao prevodilac ovog romana $i$, shodno tome, kao prevashodno "tekstualno usmereni" čitalac, suočio sam se sa tim postupkom kao s prvorazrednim čitalačkim otkrićem (takozvanom čitalačkom „poslasticom”), ali i kao sa prevodilačkim izazovom prvoga reda.

Ovaj jezički „mikroproblem" (koji ovu odrednicu "mikro" može imati samo na nivou romana kao celine, no nikako i u kontekstu važnosti konkretne scene) pojavljuje

2 Ova primedba Đerđa Papa još uvek je aktuelna, budući da se ni naredna dva prevodioca istog romana (među kojima je i autor ovog teksta) nisu usudila da menjaju ili posrbljavaju ni toponim Šarseg, niti lična imena, tako da, recimo, pomalo neobični pridev šarsegski ili šarseški i dalje ostaju u opticaju. 
se možda i u ključnoj sceni romana, kada u nekoliko poteza pripovedač opisuje tragični momenat samoubistva glavnog junaka, gimnazijskog profesora matematike i fizike, Antala Novaka (Novák Antal). ${ }^{3}$ Kostolanji - čak i u kontekstu svetske književnosti - spada u onu ne preterano veliku grupu pisaca koji ne samo što su se poigravali i „koketirali" sa smrću, sa konkretnim, dramatičnim trenutkom svršetka života, nego su ovom, ključnom momentu, tragičnom finalu svake pojedinačne ljudske sudbine, pokušali da priđu „iznutra”, drugim rečima, da ovaj u osnovi nepoznati (a po mnogima i nesaznatljivi) trenutak opišu iz jedne unutrašnje tačke gledišta, da u pripovedačkom smislu urone u njega, svesno pokušavajući da zađu u jedno suštinski vrlo teško spoznatljivo područje. Poznata je, recimo, tragična scena opisa Senekine smrti u Krvavom pesniku Neronu, kada vojnici, po Neronovoj zapovesti, starog filozofa, Neronovog dugogodišnjeg vaspitača i učitelja, strpaju u kadu i prerežu mu vene. No, u pogledu opisa scene smrti, najdalje će Kostolanjijev narator otići upravo u romanu Zlatni zmaj.

Potpuni duševni slom svog junaka Antala Novaka, pripovedač prikazuje postupno, fino gradirajući elemente koji na kraju dovode do neizbežnog ishoda. Jedan od tih elemenata je i Novakovo iznenada poljuljano poverenje u savremena, humanistička pedagoška načela u koja je dotad verovao, ali i iznenadnu skepsu u to da mu njegove egzaktne nauke, matematika i fizika, kojima se celoga života s velikom ljubavlju i strašću posvećivao, mogu pružiti bilo kakav suvisli odgovor na konačna pitanja ljudske egzistencije koja su mu se iznenada nametnula. Zanimljivo je da glavni junak, nekoliko nedelja pre totalnog psihičkog kraha, umesto svojih dotad uobičajenih dokoličarskih aktivnosti - rešavanja zadataka iz fizike ili igranja šaha sa samim sobom - odjednom počinje da čita pesme iz ciklusa Mrazovke Janoša Aranja (Arany János, 1817-1882). Reč je, dakako, o kasnim, „staračkim” pesmama velikog barda mađarske poezije XIX veka, u kojima se njegov lirski subjekt suočava sa poslednjim pitanjima ljudske egzistencije. Može se to tumačiti i kao neka vrsta junakovog konačnog razočaranja u sve ono čemu je dotad bio potpuno posvećen, u ono što je, u krajnjoj liniji, njegovom životu davalo smisao.

Sadrugim-najvećim-aujednoiposlednjim, dramatičnimjunakovim razočaranjem u nauku susrećemo se u samom opisu Novakovog samoubistva. Kostolanjijev narator u načinu na koji vodi ovu scenu kao da protivreči čuvenoj, danas pomalo već i otrcanoj, Vitgenštajnovoj floskuli da o onome o čemu se ne može govoriti, valja ćutati, utoliko što upravo o tome pokušava da progovori. Jedan od najrelevantnijih mađarskih tumača Kostolanjijevog opusa, Mihalj Segedi-Masak (Szegedy-Maszák Mihály), pozivajući se na oštroumno zapažanje francuske hungarološkinje Karolen Votren (Caroline Vauthren), tvrdi sledeće: „Poput Krvavog pesnika, i Zlatni zmaj jeste pokušaj da se predstavi unutrašnje iskustvo smrti. Dvadeset deveto poglavlje romana predstavlja »susret sa neprozirnošću, čiju neuhvatljivost tekst priznaje«" (Szegedy-Maszák 2010:279). Nije mi

3 Fabula romana mogla bi se, u najkraćem, prepričati na sledeći način: ugledni i u svakom smislu primerni gimnazijski profesor matematike i fizike, rano obudoveli Antal Novak, izvršava samoubistvo nakon što mu ćerka jedinica zatrudni s jednim njegovim đakom i pobegne od kuće, i nakon što ga (nezavisno od ćerkine trudnoće i bekstva), u društvu dvojice bivših đaka-nasilnika, brutalno pretuče učenik koga je bio prinuđen da obori na maturskom ispitu. Antal Novak naprosto ne može da podnese dvostruku sramotu koja mu je naneta, i, nemajući u skučenoj provincijskoj sredini kuda da pobegne, pribegava poslednjem koraku očajnika - samoubistvu. 
namera da po svaku cenu polemišem sa ovim stavom Votrenove i Segedi-Masaka, ali mi se čini da citat koji sledi zapravo opovrgava stanovište po kome tekst navodno priznaje svoju nemoć, odnosno, u krajnjoj liniji, daje za pravo Vitgenštajnu. Naprotiv, tekst upravo svim silama, tj. svim jezičkim sredstvima koja mu stoje na raspolaganju nastoji da prikaže unutrašnji, odveć ljudski (Niče), subjektivni, svim naučnim pretpostavkama bolno suprotstavljeni, neponovljivi trenutak smrti.

No, bez obzira na sva neslaganja oko ovako shvaćenog tumačenja moći i nemoći teksta, sa prevodilačke tačke gledišta, osnovni umetnički imperativ ostaje isti: prevodilac mora biti izuzetno oprezan kada su u pitanju ovakve, tzv. ključnescene kod Kostolanjija, mora se vratiti klasično shvaćenom načelu close readinga (pomnog čitanja, otprilike onako kako su ga formulisali rodonačelnici nove kritike), želi li da stvori prevod koji se po estetičkoj relevantnosti barem donekle može meriti sa originalom. Ta potreba za pomnim čitanjem naročito se potcrtava u svetlu jednog, gotovo teatralno istaknutog jezičkog momenta. Potrebno je, upravo iz tog razloga, ovde pribeći nešto dužem citatu, koji u sebi sadrži junakova, na egzaktnim naučnim saznanjima utemeljena očekivanja s jedne, a onda i njihovo hipotetičko? egzistencijalističko-filozofsko? pesničko? pobijanje:

Ment a pisztollyal az ajtó felé, mint aki valakit üldöz, egy láthatatlan ellenséget, kifelé igyekezve, s ott közvetlenül a küszöbön, a nagy vaskályha mellett a csövet magára fordította.

Nem a szívére, nem is a halántékára. A szájába vette, mint valami ételt, melyet szeret, a fogai közé harapta. Ez a legbiztosabb.

Csak egy pillanat lesz az egész. Látni fogja a fényt, mely kilövell a csőből, nyelvét, szájpadlását megperzselve, majd akár viharnál a villámlás után a mennydörgés, robaj hallatszik, mely mindennél nagyobb. Talán a puskapor szagát is érzi, s egy utolsó fájdalmat, mely semmihez se hasonlítható. Csak egy másodperc. Aztán, mint a szegény verebek az üvegbúra alatt.

Most elsütötte a ravaszt.

Nem így volt, nem így volt. Nem egy pillanatig, nem egy másodpercig tartott. Fejében, mint az órában, melyet összetörnek, megállt az idő. De mintha leszakadt volna a padlóval a földszintre, vele együtt pedig mintha rázuhant volna a mennyezet, mintha összedőlt volna az egész gimnázium s az égbolt is, az égbolt.

A golyó, minthogy a csövet tudatosan fölfelé irányította, szétroncsolta nyúltagyát. Novák Antal a küszöbön átesve a kályha mellé bukott. Egy párat mozdult. Akkor beállt a nyugalom. ${ }^{4}$ (Kosztolányi 1968: 240-241)

Pasus od ključnog značaja u opisu samoubistva, u kojem se junakova, na nauci zasnovana očekivanja ruše, ovoga puta konačno i neopozivo, počinje, dakle, rečenicom, Nem így volt, nem így volt (nije bilo tako, nije bilo tako), da bi se, nakon morbidno detaljnog opisa putovanja metka kroz mozak, završio ovako: $s$ az égbolt is, az égbolt (a i nebeski svod, i nebeski svod). Po mišljenju priređivača kritičkog izdanja Zlatnog zmaja (koje je još uvek u fazi pripreme), Lasla Bengija (Bengi László), ovo ponavljanje svakako mora imati osobenu funkciju naglašavanja, „skretanja čitaočeve pažnje na

4 Kurzivi su moji (M.Č.). 
dramatičnost trenutka." (Bengi 2011: 122) Mišljenja sam, međutim, da je ovde, pored očiglednog ponavljanja, prisutna još jedna, ne preterano skrivena namera autora, a to je da stvori, ako ne baš čistu rimu, a ono barem asonancu, odnosno svojevrsni eufonični efekat između prve i poslednje rečenice pasusa (Nem így volt, nem így volt - s az égbolt is, az égbolt). Poznato je da je u mađarskoj književnosti Endre Adi (Ady Endre, 1877- 1919) vrlo često koristio rimovana ponavljanja, pa su veliki parodičar Friđeš Karinti (Karinthy Frigyes, 1887-1938), a zajedno sa njim i Kostolanji, koji se žestoko protivio pravljenju nekritičkog kulta Adija, najviše izvrgavali ruglu upravo ovaj Adijev postupak. Stoga bi se možda ovaj neočekivani Kostolanjijev postupak ovde mogao shvatiti i kao neka vrsta srkivene travestije Adija, što dramatičnosti opisanog trenutka u romanu daruje izvesnu ironičnu crtu i kao da predstavlja kontrapunkt strahovitoj tragediji glavnog junaka.

Nevolja je, međutim, u tome što je Kostolanji, taj veliki majstor rime u vlastitoj poeziji, rimu u prozi svesno izbegavao, verovatno je smatrajući pribežištem diletanata. No, nešto ga je ipak moralo podstaći da upravo na ovo mesto, na ovo, kako bi se Đerđ Tverdota (Tverdota György) - istina, povodom jedne pesme Atile Jožefa - izrazio, "emocionalno dno" (Tverdota 2005: 152) romana ubaci upravo jednu ovakvu, neočekivanu rimu. Moglo bi se pretpostaviti da je želeo, s jedne strane, da i grafički naglasi veličinu i tragičnost opisanog trenutka, a s druge strane, moguće je i da je, dajući tom grafičkom naglašavanju jedan patetičan, sa stanovišta sopstvene poetike gotovo diletantski prizvuk, pokušao da održi ironičnu distancu između tragične sudbine svog skrhanog, mada, u krajnjoj liniji ipak malograđanski ustrojenog junaka i nekog sopstvenog (pretpostavljenog i implicitnog) sistema vrednosti.

No, ma koliko izazovna bila, ovakva nagađanja prevodiocu nisu nužno od velike koristi. Prevodiočev zadatak u ovom slučaju bio bi taj da se sa ovom dvostrukom daktilskom rimom izbori tako što će je i u prevodu na neki način učiniti vidljivom. Trebalo bi, dakle, pronaći odgovarajući ritam i rimu (ili barem asonancu) u ciljnom jeziku. U konkretnom slučaju, prevodilac je, nakon dužeg mučnog premišljanja, teška srca ipak morao odustati od daktilske ritmičke sheme. Ostalo je još traženje adekvatne rime ili nečega što bi na rimu moglo nalikovati. Kao što se iz gore navedenog prevoda vidi, imenica égbolt doslovce bi se mogla zameniti izrazom nebeski svod, ali malo se reči koje bi se u ovom kontekstu mogle upotrebiti bez prevelikog odstupanja od smisla, rimuje s rečju svod. U obzir bi možda mogla doći imenica pod kao pod gimnazije koji se metaforički stropoštava na glavu junaka-samoubice, no i to bi, zapravo, značilo neku vrstu učitavanja i udaljavanja od smisla originala, i to u pravcu svojevrsne groteske, a grotesku bi - koja u nekim drugim tekstovima Kostolanjiju uopšte nije strana, naprotiv - u ovoj konkretnoj sceni ipak trebalo izbeći. Nebeski svod, dakle, otpada. 0stalo je još nekoliko alternativa: recimo, naprosto upotrebiti reč nebo. Sa rečju nebo se pak javlja jedna još neprijatnija poteškoća, to, naime, da se sa njom rimuje veoma mali broj reči, a prva koja je prevodiocu pala na pamet i koja ga dugo nije napuštala, potrcrtavajući grotesknu situaciju u kojoj se našao, vrlo je nepristojna i nikako ne priliči Kostolanjijevom istančanom rilkeovskom lirskom senzibilitetu. Ostaje još mogućnost odustajanja od prevodilačkog principa „reč za reč", pa, shodno tome, zameniti nebo nekim semantički srodnim izrazom. Na kraju sam se odlučio za izraz nebeska tela, tj. nebesko telo svako, što se rimuje sa prvom rečenicom pasusa nije bilo tako. Rima svakotako ne spada, razume se, u bogatije rime srpskog jezika, ali, s obzirom na to da je 
momenat nekako valjalo naglasiti, nekakvo se rešenje ipak moralo doneti. Ako uz to još uzmemo u obzir to da je Antal Novak bio i astronom-amater, te da je imao durbin u bašti, nalik teleskopu, kojim je često posmatrao zvezde, ogrešenje o duh originala nije, čini se, preveliko. Evo, dakle, celokupnog prevoda scene Novakovog samoubistva:

Krenuo je prema vratima s pištoljem u ruci, kao da goni nekoga, nekog nevidljivog neprijatelja, hitao je napolje i onda je, na samom pragu, pored velike gvozdene peći uperio cev u sebe.

Ali ne u srce, ne ni u slepoočnicu. Stavio ju je u usta poput neke hrane koju voli, i zagrizao je zubima. To je najsigurnije.

Potrajaće samo tren. Ugledaće svetlost koja će grunuti iz cevi i spržiti mu jezik i gornje nepce, pa će se, kao za vreme oluje grmljavina posle munje, začuti prasak, jači od svega. Osetiće možda i miris baruta i jedan poslednji bol koji se ni sa čime ne može uporediti. Jedan sekund samo. A onda, kao oni siroti vrapci pod staklenim zvonom.

Povukao je obarač.

Nije bilo tako, nije bilo tako. Nije trajalo tren, nije trajalo sekund. U glavi mu se, kao u satu koji se polomio, zaustavilo vreme. I kao da se zajedno s podom stropoštao u prizemlje i kao da se s njim i tavanica sručila na njega, kao da se srušila čitava gimnazija, a s njom i nebesko telo svako, nebesko telo svako.

Metak mu je, budući da je cev svesno uperio nagore, smrskao produženu moždinu. Antal Novak je pao preko praga i skljokao se kraj peći. Trgnuo se još nekoliko puta. A onda je nastupila tišina. ${ }^{5}$ (Kostolanji 2012: 315-316)

Šta god da je, međutim, razlog i povod jednog ovakve, naknadne prevodilačke "samolegitimacije", svoj sud o istinskim dometima i estetičkoj valjanosti upravo ovog izbora, moći će da pruži tek eventualna kritika prevoda ili će se pak odgovor na pitanje o opravdanosti ovakvog rešenja u jednoj ovako "neuralgičnoj tački" celokupnog teksta moći implicitno iščitati iz srpske recepcije ovog romana. Dosadašnja čitanja, tačnije, njihova pretežna usmerenost na sadržinsko-tematski i etički segment dela, ${ }^{6}$ ne daju prevodiocu mnogo razloga za veselje, i kao da još jednom potvrđuju tezu o večitom prevodiočevom fijasku da ono što je u delu poezija (a u Kostolanjievom slučaju je to sama srž romana) valjano pretoči u medijum ciljnog jezika.

\section{LITERATURA}

Bengi, L. 2012. Elbeszélt halál. Kosztolányi-tanulmányok [Ispripovedana smrt. Studije 0 Kostolanjiju]. Budapest: Ráció Kiadó.

Kosztolányi, D. 1968. Aranysárkány [Zlatni zmaj]. Budapest: Szépirodalmi Könyvkiadó.

5 Kurzivi su moji (M.č.).

6 Mislim tu u prvom redu na jedina dva relevantna domaća prikaza ovog romana, iz pera Nataše Anđelković (Anđelković, Nataša: Povest o blatištu. U: Pečat, Beograd, br. 258, 8. mart 2013, str. 57) i Teofila Pančića (Pančić, Teofil: Blatni demoni Bačke. U: Vreme, Beograd, br. 1163, 18. april 2013, str. 58-59). 
Kostolanji, D. 2012. Zlatni zmaj. Sa mađarskog preveo [i pogovor napisao] Marko Čudić. Vršac: Književna opština Vršac.

Papp Gy. 1985. Egy Kosztolányi-regény szerbhorvát kiadásának fordítástörténeti tanulságai [Istorija prevoda - pouke iz srpskohrvatskog izdanja jednog Kostolanjijevog romana]. Híd (Novi Sad). God. XLIX, br. 10, 1355-1362.

Szegedy-Maszák, M. 2010. Kosztolányi Dezső. Pozsony [Bratislava]: Kalligram.

Takács, L. 2012. Néhány megjegyzés a Nero, a véres költő forrásaihoz. Kosztolányi Dezső és Oscar Wilde [Nekoliko primedbi u vezi sa izvorima za roman Krvavi pesnik Neron. Deže Kostolanji i Oskar Vajld]. Kalligram. XIX. god, jul-avgust 2012, 27-31.

Tverdota, Gy. 2005. Határolt végtelenség. József Attila-versek elemzései. [Ograničeni beskraj. Tumačenja pesama Atile Jožefa]. Budapest: 0siris

\section{SUMMARY}

\section{A SPECIFIC LYRICAL ELEMENT IN DEZSŐ KOSZTOLÁNYI'S NOVEL THE GOLDEN KITE SEEN FROM A TRANSLATIONAL POINT OF VIEW}

The great classic of modern Hungarian literature, Dezső Kosztolányi (1885 - 1936), a prolific poet in the first place, has put a significant emphasis on the sophisticated elaboration of linguistic expressionsin his prose writings as well. Theselinguistic, stylistic features play a crucial role in certain points of Kosztolányi's novels in the thematic and existential sense. This paper attempts to point out to a momentum of this kind in one of Kosztolányi's novels, Aranysárkány (The Golden Kite). The narrator employs a rhyme in the most dramatic moment of Antal Novák's suicide, adding a special, irony-loaded quality to the unspeakable dreadful violent moment of death, which is rarely touched upon in literature. From the perspective of the text-oriented reader, the translation of this specific part of the text is crucial, since the reader needs to become aware of the linguistic and stylistic emphasis of this specific segment of the text.

KEYWORDS: textual ('narrow') reading, emphasized momentum, prose rhyme, translation difficulties. 